\title{
The Application of Lesson Study in Teaching English as a Foreign Language
}

\author{
Abdullah COŞKUN \\ Abant Izzet Baysal University
}

\begin{abstract}
:
Lesson Study is a professional development method involving a group of teachers working collaboratively towards a jointly prepared research lesson. The purpose of this study is to apply Lesson Study in the English as a Foreign Language context of Turkey. The participants are three English instructors and 18 students in the English Preparatory Program at a Turkish university. The instructors prepared a research lesson, and the lesson was presented by one of the instructors while the other instructors were observing students. Following the first lesson, a post-lesson discussion among the instructors was carried out, and students filled out an open-ended survey about the lesson. After necessary revisions were made in line with the participants' suggestions, the lesson was presented to another group of learners at the same level, and the opinions of students and teachers about the revised lesson were collected once again. The analysis of the qualitative data revealed that Lesson Study led to the improvement of the research lesson. Moreover, it was found that Lesson Study was considered beneficial by the instructors as a means of professional development.
\end{abstract}

Keywords: lesson study, professional development, English as a Foreign Language

.

İnönü University Journal of the Faculty of Education Vol 18, No 1, 2017

pp. 151-162

DOI: $10.17679 /$ inuefd.297845

\section{Suggested Citation}

Coşkun, A. (2017). The Application of Lesson Study in Teaching English as a Foreign Language, Inonu University Journal of the Faculty of Education, 18(1), 151-162. DOI: 10.17679/inuefd.297845 


\section{INTRODUCTION}

It is common knowledge that the teacher plays one of the most significant roles in students' success (Hill, Rowan, \& Ball, 2005). Therefore, the importance attached to continuous professional teacher development has increased in recent years (Kourieos, 2012). It is now a widely accepted view that teachers need to approach professional development as a crucial component of their teaching career (Harding, 2009) so that they can catch up with and incorporate the most recent developments in the field (Karabenick \& Noda, 2004). Although there have been various traditional professional development methods for teachers, the constructivist theory of learning has favored the use of inquiry-based approaches (Rock \& Wilson, 2005). Lesson Study (LS) originating in Japan's educational sphere in the 20th century is one of these inquirybased approaches inspired by ideas, such as reflection, collaboration, and classroom practice (Johnson, 2009). Because of the collaboration among teachers, LS is described as a means of joint professional development (Hargreaves, 2012).

LS is also defined by Lewis (2002) as a teacher-led instructional improvement cycle through which teachers work collectively to fulfill a series of steps. These steps can be summarized as follows: identifying goals for student learning, preparing a research lesson, teaching/observing the lesson (one of the LS group members takes the responsibility of teaching the lesson while other members observe students), revising the lesson based on the data collected through post-lesson discussions among the teachers and interviews/open-ended surveys with students, and re-teaching the revised lesson to a different group at the same level (Stigler \& Hiebert, 1999). It is also argued by Stigler and Hiebert (1999) that the same data collection procedures are utilized at the end of the revised lesson, and the LS process can be repeated if more revisions are necessary. As can be realized from the cyclical process of LS, it embodies a variety of professional development strategies, such as ongoing collaboration, peer observation, and making a detailed assessment of how students are reacting to the lesson (Darling-Hammond \& McLaughlin, 1995).

Considering that the research lessons are prepared together by a group of teachers, LS is similar to action research leading to teacher research and learning through collective lesson planning, observation, and reflection (Dudley, 2011; Rock \& Wilson, 2005). One of the most important differences between LS and other professional development methods is that the focus of LS is on student learning, not on the evaluation of the teacher (Roback, Beth, Legler, \& Moore, 2006). Similarly, as underlined by Stigler and Hiebert (1999), LS is carried out to develop an effective lesson and to understand how the lesson should be restructured to promote students' better understanding of the lesson; therefore, when a problem occurs during the LS, it is the lesson plan from which the problem arises, and not the teacher who has taken the responsibility to teach the lesson content. That is why LS paves the way to a safe environment for collaboration (Tsui \& Law, 2007). The combination of collaboration and focused observation within LS are considered to be powerful tools for facilitating teacher growth, pedagogy, and the ability to understand student learning (Murata \& Takahashi, 2002).

As the general rationale behind LS is that "evidence of effective classroom practice is proved only in the classroom" (Tanaka, 2007, p.150), it is often thought that the theoretical background of LS is closely associated with the Situated Learning Theory (Lave \& Wenger, 1991). According to this theory, learning is a social phenomenon contributing to the construction of knowledge through the cooperation of a group of teachers rather than its transmission from one person to another. It would be a fair assumption that using LS, teachers could improve themselves professionally while exchanging ideas and collaborating on the revision of a research lesson.

\section{Significance of the Study}

Although it originated in Japan, LS has become one of the most popular approaches to teacher professional development in the United States (Lewis, Perry, Hurd, \& O'Connell, 2006) and in other countries, such as Singapore, Chile and the UK (Dudley, 2011). Conversely, there have been a few studies involving LS only in the field of mathematics education in Turkey (Eraslan, 2008; Kıncal \& Beypınar, 2015). As justified by Eraslan (2008), teachers in Turkey tend to work in isolation and do not have the opportunity to observe each other because of the common belief that the classroom is private and should not be interrupted under any circumstances. He also points out that some of the professional development programs in Turkey cannot go beyond short term workshops. Thus, he argues that broad-based professional development processes, such as LS should be applied in Turkey. 
Even though LS was applied in many other fields, such as mathematics and science education (Stigler \& Hiebert, 1999), only a few studies illustrating the application of LS in English as a Foreign Language (EFL) contexts in the world can be found in the relevant literature (Lee, 2008; Tasker, 2014; Nami, Marandi, \& Sotoudehnama, 2015). Moreover, a study illustrating how EFL teachers can come together and carry out LS has not been conducted in Turkey. Considering the lack of literature in Turkey and the professional benefits of LS as discussed above, there is a need to develop LS in the Turkish EFL context. Thus, the aim of the current study is to present the steps of LS involving three EFL instructors and 18 students at a university in Turkey. This study is intended to increase awareness about professional development for Turkish EFL teachers and to help facilitate the integration of LS into both curriculum and professional development programs.

\section{LITERATURE REVIEW}

As this study deals with the use of LS as a means of in-service teacher development in the EFL context, only the studies found relevant are reviewed. One of these studies was conducted by Nami, Marandi and Sotoudehnama (2015), who carried out a case study dealing with the opinions of five EFL teachers about the effects of LS on their computer assisted language learning (CALL) professional development. Participants' answers to interview questions as well as their reflection journals were analyzed. It was found that they appreciated the teaching practice and peer observation for increasing their pedagogical knowledge related to technology and their confidence in teaching with technology.

On the other hand, Tasker (2014) investigated how LS promoted teacher learning for three EFL teachers. In the study, the teachers took part in a fourteen-week experiment. Content analysis was used to analyze the data collected through teacher journal entries, teacher and administrator interviews, meetings with the school administrators, and the research lesson plan prepared by the teachers. It was revealed that the involvement of school administrator in LS is necessary to affect change.

In another study, Lee (2008) explored English teachers' professional development using LS in Hong Kong. In his study, a group of EFL teachers worked cooperatively to improve their instruction on wh- questions. He concluded that by means of LS, teachers involved in critical self-reflection, developed professional knowledge as well as pedagogical skills, and became more aware of students' learning needs. Conversely, teachers had problems regarding the additional workload and time commitment LS brings with it, which could undermine the benefits of LS.

Now that there is a negligible amount of literature in the EFL context, this study aims to bridge the research gap in the field of EFL by illustrating how to apply LS. Therefore, the present study first aims to present the findings related to how LS procedure affected the improvement of a lesson. Second, the study intends to investigate the opinions of teachers regarding the benefits of LS and its applicability in their working context. In line with these objectives, two research questions were formulated:

1. How does Lesson Study lead to the improvement of an EFL lesson?

2. What do English teachers think about the benefits of Lesson Study and its applicability to their teaching context?

\section{METHOD}

The main objective of this study is to make a thorough analysis of the experiences of teachers and students taking part in the LS process. Using the framework proposed by Cerbin and Kopp (2011), a lesson plan focusing on the teaching of past passive structure was prepared by three EFL teachers. At the end of the lesson, necessary feedback as to how the lesson could be improved was obtained from teachers and students. Afterwards, necessary revisions were made in the lesson, and the revised lesson was presented to another group of students at the same level. Similarly, opinions of teachers and students were collected at the end of the revised lesson. Burns (1999) describes studies similar to the current one as action research studies because a group of teachers collaborated for the improvement of the lesson they jointly prepared. Additionally, because the data were collected by means of open-ended student/teacher surveys, the student observation checklist, and the post-lesson discussions among teachers, this study can also be referred to as a qualitative study. 


\section{Participants}

The present study is carried out in the context of an English Preparatory Program at a state university in Turkey. When students are eligible for enrollment at an English medium department at a Turkish university, they have to pass an English proficiency test at the beginning of the students' first academic year. Scores obtained from this test are used to decide whether their English proficiency is at a sufficient level to advance to their departmental courses.

The students who were invited to the LS were A2 level students as described in the Common European Framework of Reference (CEFR). A total number of 18 students accepted to take part in the study. Eight of them attended the first research lesson, and ten of them attended the revised lesson. On the other hand, three non-native university-level EFL instructors (two female, one male) volunteered to participate in the LS cycle.

\section{Instruments}

The data collection instruments were determined by the teachers taking part in the LS process in line with the purpose of the study. A pre-test with five multiple choice items dealing with past passive voice was distributed to students before the beginning of the lesson. Then, the same questions were given at the end of the lesson (i.e., post-test) to evaluate students' progress in the post-lesson discussion among the teachers.

In addition, both for the first and the revised lesson, an observation checklist designed by Dudley (2011) was used so that students could be observed during the lesson and their progress could be reported in the post-lesson teacher discussions. Furthermore, an open-ended survey (in Turkish) including the following questions suggested by Dudley (2011) was distributed to students to obtain their opinions about the research lesson: 'What did you enjoy most about that lesson?' and 'If the same lesson is being taught to another group what would you change. Why would you change that aspect?'

During post-lesson discussions among teachers, positive and negative aspects of the lesson were discussed and specific attention was paid to the following question formulated by Dudley (2011): 'What aspect(s) of the teaching technique could be adjusted next time to improve the progress of each pupil?' Finally, teachers' opinions about the benefits and applicability of LS were revealed by means of open-ended survey questions ('Do you believe that the second lesson was better than the first one?', 'Do you find LS beneficial?' and 'Do you think LS is applicable to the English teaching context of Turkey?').

\section{Trustworthiness and Ethical Considerations}

In terms of trustworthiness and ethical considerations, some strategies were followed. The LS guidelines proposed by Cerbin and Kopp (2011) were used in this study as they are based on the Lesson Study Project in which over 100 lesson study teams participated. Moreover, the researcher did not involve in lesson preparation or express his opinions about the lessons. He only took the role of post-lesson moderator of group discussions, and collected data from students and teachers. To triangulate the data, opinions of not only teachers but also students were collected about the research lessons. Additionally, different data collection tools, such as a pre-tests/post-test, an observation checklist and an open-ended survey were used to collect data.

The post-lesson discussion meetings and the lessons were arranged after school hours when the teachers and students were available. Instead of tape recording, the researcher only took notes of the key points brought up in the post-lesson discussions at the request of one of the teachers. Only students and teachers who volunteered were invited for the lesson. Before the lesson started, each student was informed about the LS procedure. The teachers were also introduced to the class and students were told that the purpose of the observation was not to evaluate their performance, but to help understand how the lesson could be improved.

\section{Data analysis}

The qualitative data collected during the LS cycle both from students and teachers were analyzed by means of content analysis which led to common themes about the LS process. Quotations of the participants were used to support the emerging themes and to provide a rich description of these themes (Schilling, 2006). 


\section{Research Procedure}

The LS process followed in the study is described in detail under the titles of the steps proposed by Cerbin and Kopp (2011):

-Form a team: In this study, a team of three instructors worked together on a research lesson. Having specified regular meeting times, teachers were first oriented to the concept and the general principles of LS. In this study, one of the teachers accepted the responsibility of teaching the lesson while the other two teachers were in charge of observing students.

-Develop learning goals: The teachers brainstormed about important learning goals. From long-term goals, such as being able to speak English fluently, a narrower lesson-specific objective was determined. The teachers agreed that the lesson should focus on the instruction of past passive voice through a content of historical events because they believed that students had difficulty in this structure. Therefore, the objective of the lesson was specified as follows: "By the end of the lesson, students will be able to recognize and use the passive voice in the simple past tense." The most important point mentioned in the meeting was that the lesson needed to be designed in line with the general principles of Communicative Language Teaching $(C L T)$, which enables communication in the classroom through interaction in the target language by means of authentic texts (Nunan, 1991). It was decided that the duration of the lesson would be 50 minutes.

-Design the lesson: All the teachers had some activities in mind to teach the past passive voice. The following procedures were decided upon as the warm-up/presentation, practice and production stages of the first research lesson:

In the warm-up stage of the lesson, students $(\mathrm{N}=8)$ watched part of a film on YouTube about some of the most important inventions of the Industrial Revolution (e.g., printing press, lamp, telephone) for some general post-listening questions. After the film, which took approximately two minutes, the teacher asked questions, such as "What are some of the inventions in the film?" and "Who was the telephone invented by?"

After a class discussion about the film, each pair of students was given different cards about historical events to find the correct match on their desks. The cards were organized in three sets that make a meaningful sentence. On one of the cards, for example, there was a picture of Christopher Columbus while a map of America is given on another card. On the other card, the verb "discover" was written. Students were expected to match the given cards randomly which lead them to eight different past active voice sentences. Students were also expected to write the past simple forms of the verbs for each match on the matching cards. After the completion of this matching activity, the teacher stuck randomly on the board the bigger versions of these cards, and invited volunteering students to do the same matching. Students were then asked to think of any other ways to make the sentences on the board by changing the position of the cards with the subject and the object.

In the practice part of the lesson, after the teacher elicited the past passive voice structure from the students, a text about the discovery of the X-ray was reflected on the board, and students underlined the sentences including a past passive voice structure. Then, the teacher gave students a handout on which there were some sentences with both active and passive voice and asked students to find which ones were active or passive voice. In addition, students were also expected to change active voice sentences into passive.

In the last part of the lesson, which is the production stage, students stood up in front of the class and asked the questions reflected on the board (e.g., Were you taken to hospital?) to their partner. They were expected to produce at least one additional question related to the main one. For example, for the question "Were you bitten by an animal?", students were expected to add "Where did it happen?" They were encouraged to change their partners for different questions on the board.

-Teach \& Observe: During the teaching hour, two of the teachers who were in charge of observing students sat on two different sides of the classroom. One of the group members sat on the left hand side of the classroom to observe students nearby while the other teacher sat on the right hand side and paid attention to students there. The research lesson started with a short multiple choice pre-test including questions 
related to the focused structure. In addition, a post-test was given at the end of the lesson. An observation checklist including the activities in the lesson plan was given to each teacher for student observation. Observers wrote comments about students' progress next to each activity.

At the end of the lesson, written works students completed as part of the lesson were also collected to aid the post-lesson group discussion among teachers. At the end of this stage, students were given an openended survey and were asked questions about what they liked in the lesson and what they would change if the lesson were taught again.

-Analyze \& Revise: The student observation checklists were discussed in the post-lesson discussion. The difficulties students encountered during the lesson were revealed by each observer and necessary actions to take were discussed. Starting from the LS member who took the role of the teacher in the group, each LS member gave feedback about possible ways to revise the lesson in line with the objective of teaching past passive voice in a communicative way within the context of historical events.

\section{FINDINGS}

The findings of the study are based on the data collected at the end of the first lesson and the revised lesson. First, teachers/students' points of view about the first research lesson are presented. Second, the revisions in the lesson plan made in line with teachers and students' feedback are explained. Third, teachers/students' opinions about the revised lesson presented to another group of students are discussed. Finally, teachers' beliefs about the benefits of LS are illustrated.

\section{Findings about the First Lesson}

Teachers' Points of View

In the post-lesson discussion after the first lesson, the positive and negative issues raised by the teachers were analyzed, and the summary of the key points can be categorized as follows into positive and negative feedback:

Positive Feedback: The idea of pre/post-test; using visual materials; monitoring students; trying to elicit the grammar rule rather than directly teaching it; the use of demonstrations by the teacher for difficult instructions; starting the lesson with a film; effective code-switching to explain critical grammar points; effective pair/group work organization.

Negative Feedback: The focus on the form (i.e., past passive voice) and mechanical drills; the neglect of the writing skill; the mismatch between some verbal instructions and the instructions on some materials; the insufficiency of time for students to take note of the items on the board; some typographical and grammar mistakes on some handouts.

On the other hand, observing students revealed that the lesson posed some problems to some students. The problematic points that emerged as a result of student observation are as follows:

The listening track was challenging; some of the past participle forms on the materials were not familiar; some instructions were misunderstood; some students slowed down other students as time was given to each student to complete the activities; students did not have fun during the activities; additional questions could not be generated about the given prompts in the production part of the lesson; some verbs on the matching cards were beyond students' level; underlining sentences with past passive form took excessive amount of time.

\section{Students' Points of View}

At the end of the first research lesson, students were given an open-ended survey including a question dealing with what they enjoyed most about the lesson. Students indicated that they enjoyed the following points most: the teaching of grammar in an indirect and fun way, the use of visual activities, the idea of using pre/post-tests, teacher's support and monitoring. To illustrate these points, two students referred to with a number below (Student 4: ST 4) made the following comments: 
ST 4: I enjoyed the idea of pre/post-test. I think, my pre-test score was terrible but my post-test score was good.

ST 7: The teacher used a lot of visual activities which made the lesson fun.

Related to the other survey question about the changes students deem necessary for the improvement of the lesson, they claimed that some simplification or omission in some activities in the lesson should be considered. For example, one student suggested that there were many unknown words in the text used in the lesson, and thus the text should have been simplified:

ST 2: In the text to be underlined, there were many unknown words. The text should have been simplified.

It was also indicated by another student that it was boring to have the same matching cards both on the desk and on the board. Therefore, these activities can be omitted or different cards can be used for the board:

ST 6: The idea of the same matching cards both on the desk and on the board was boring. So, one of these activities can be omitted or different cards can be used for the board.

Another student also commented that the questions they talked about with a partner at the end of the lesson were very difficult.

\section{Revisions in the Lesson Plan}

In accordance with students' feedback and the post-lesson discussion among teachers, necessary revisions were made in the lesson. It was agreed upon by the teachers that the revised lesson would be retaught to another group of students $(\mathrm{N}=10)$ at the same level.

The second lesson was slightly different from the first lesson in line with students and teachers' suggestions to make the lesson more communicative, time efficient and easy for students to follow. This time, as there was already a matching activity requiring students to match the randomly given cards on the desk, the same matching on the board was minimized to only one sentence so that the grammar rule could be elicited by using the sentence on the board. In addition, the text about the discovery of the X-ray used in the first lesson was skipped in the revised lesson. The number of sentences on the handout requiring students to differentiate between active and passive sentences was also lowered to half.

Some of the key stages of the revised lesson were as follows: Unlike the first lesson, after students decided whether the sentences were in the form of active or passive structures, each student was given a picture including the photo of the subject (e.g., Shakespeare) and the object (e.g., Hamlet) as well as the verb (e.g., write) that were necessary to make a sentence. After each student constructed a sentence and said it to his/her partner, he/she was expected to pass the picture to the person sitting next to him/her.

Another difference between the first and revised lesson was that students were given fewer and easier questions to ask to their partners in the production part of the revised lesson. Moreover, additional questions were provided (e.g., 'Were you taken to a hospital? Who took you there? Why did he/she take you to the hospital?').

\section{Findings about the Revised Lesson}

\section{Teachers' Points of View}

During the revised lesson, students were observed by the teachers by means of the same observation checklist used for the first research lesson. The summary of observation findings is as follows:

The word 'conquer' was not understood; students tended to make all the sentences in the production part of the lesson in passive form (overuse of the focused grammar); were shy during the speaking activities; did not have enough intellectual information related to some of the pictures; preferred working with the same partners during the speaking activity at the end of the lesson. 


\section{Students' Points of View}

The students observed in the revised lesson responded to the same questions that were asked in the first lesson. When asked what they liked most about the lesson, they commented that it was good to present the lesson using visual materials; also, as can be realized from the following comment, standing in front of the class to talk to friends was considered to be the most enjoyable part of the lesson:

ST 7: I liked standing up and talking to my friends about the questions on the board.

Finally, in terms of the question asking their opinions about the things that they would change to improve the lesson, while one student indicated that standing in front of the class for the speaking part caused some confusion about who to talk to, the other students saw no need to make any further revisions:

ST 5: I would not change anything. Everything was good.

\section{Teachers' Beliefs about LS}

At the end of the LS cycle, teachers responded to an open-ended survey including the question 'Do you believe that the second lesson was better than the first one?' All the teachers thought that the revised lesson was better, more manageable for the students and more communicative after making necessary revisions in line with the findings obtained at the end of the first lesson. Their relevant comments are as follows and referred to with a number (Teacher $1: T$ ):

T 1: The second lesson was better. After having seen the weaker points of the previous lesson, the LS group developed the second lesson. Some mistakes made by the first lesson were corrected.

T 2: At first, we had materials which took longer than we had expected. Later, after realizing how much time the materials took, we moderated the final lesson and put more emphasis on our target which was to get students to speak.

T 3: When compared to the first lesson, the students were more active in the second lesson. They spoke much more than the first lesson. Therefore, the second lesson was more successful in terms of the target skill, which was speaking.

Another important question they responded to was 'Do you find LS beneficial?' All the teachers held the idea that LS is beneficial as a means of revealing the parts of the lesson which students have difficulty with, and as a way of professional development through which teachers learn from one another. However, one of the teachers ( $\left(\begin{array}{l}\mathrm{L} \\ 2\end{array}\right)$ expressed the concern that there might not be enough volunteering teachers to carry out LS projects. Their responses are as follows:

T 1: Yes. To be able to see the weak points of the lesson and to see where students struggle more.

T 2: It is efficient only if there were enough volunteer instructors to do so. It might also be more beneficial if each teacher in the LS group get the chance to try the materials they are planning to use in the lesson study earlier with his/her classroom.

T 3: I find the LS beneficial. These types of studies are kind of professional development. In this way, teachers can learn a lot from each other. It is normal that teachers' methodological knowledge becomes out-of-date after a certain period of time and students' profiles change every year. Therefore, LS is a good way to improve ourselves professionally.

Finally, when asked the question 'Do you think LS is applicable to the English teaching context of Turkey?', T 1 responded negatively because of the lack of English teachers working for a single lesson. T 2 also commented negatively by stating that being observed in the classroom is not accepted by Turkish teachers. Conversely, T 3 was positive about the applicability of LS to the English teaching context of Turkey. Their comments are as follows:

T 1: It is difficult because in Turkey, there are not enough teachers for every class. So for three or four teachers to come together to produce and study a single lesson is hard. 
T 2: As far as I am concerned, being observed is not welcomed among most Turkish instructors. However, this attitude can be moderated if the policies of the institution change.

T 3: I think this type of LS is applicable to the ELT context of Turkey. At least, it should be applied to universities. Two or three teachers should come together, work together towards a lesson and give feedback to each other.

\section{DISCUSSION AND CONCLUSION}

In this study, LS procedures were followed to answer two research questions: 'How does Lesson Study lead to the improvement of an EFL lesson?' and 'What do English teachers think about the benefits of Lesson Study and its applicability to their teaching context?'

Throughout the paper, the stages leading to an answer to the first research question were illustrated by findings obtained from both teachers and students. To improve the research lesson mentioned in this study, the main data were the students' and teachers' opinions about the research lesson jointly prepared to teach the past passive structure to a group of A2 level students in line with CLT.

During the first lesson, teachers who were responsible for observing students sat on different sides of the classroom to be able to observe more students. Based on student observations, teachers were able to detect the problems students experienced during the lesson and made relevant suggestions to improve the lesson for the second implementation. After the lesson, students' opinions about positive and negative aspects of the lesson were also collected. The analysis of the data revealed that the research lesson was slightly beyond students' level and was more grammar-oriented rather than communication-oriented. The fact that grammar teaching dominates over communication-oriented teaching in different educational levels in the Turkish EFL context has also been highlighted by many researchers (Tercanlıoglu, 2004; Kırkgöz, 2007; Şad, 2010; Dinçer \& Yeşilyurt, 2013; Uysal \& Bardakçı, 2014).

Necessary revisions in the flow of the first lesson plan were made and the revised lesson was retaught to another group of students. The data were also collected both from students and teachers at the end of the second lesson. The cyclical process of LS (Darling-Hammond \& McLaughlin, 1995) applied in the present study yielded a second lesson which was considered more effective, more suitable to students' level and more communicative in nature. The LS process is believed to encourage teachers to improve the research lesson, take part in deeper reflection about the teaching practice and engage in professional development (Lewis, 2002; Tsui \& Law, 2007).

In the relevant literature, it is argued that by taking part in LS, teachers can extend their pedagogical content knowledge required for reform-minded teaching (Fernandez, 2005) as they critically investigate their practices by means of LS (Stepanek, Appel, Leong, Mangan, \& Mitchell, 2007). It also paves the way for "increased knowledge of subject matter, increased knowledge of instruction, increased ability to observe students, stronger collegial networks, stronger connection of daily practice to long-term goals, stronger motivation and sense of efficacy, and improved quality of available lesson plans" (Lewis, Perry, \& Hurd, 2004, p. 19).

The second research question focusing on the benefits and the applicability of LS led to the finding that teachers regarded LS as a means of revealing and revising the parts of the lesson with which students have difficulty and as a way of collaborative professional development. However, one of the teachers argued that it might be difficult to find a group of teachers who may want to volunteer to take part in such LS projects.

As for the applicability of LS to their teaching contexts, two issues were underlined by the teachers. One of them was the lack of EFL teachers who could spend a lot of time and energy for a single lesson. This finding corroborates the argument that because of the workload of English teachers in Turkey, it might be hard for them to have enough time for professional development opportunities (Daloğlu, 2004; Özmusul, 2011; Seferoğlu, 1996). In a study carried out abroad, it was also found that EFL teachers had problems concerning the additional workload and time commitment LS requires (Lee, 2008). 
The other concern expressed by another teacher was related to the traditional classroom culture in Turkey not allowing observers into the classrooms; however, the teacher making the comment suggested that this situation could change if necessary institutional efforts were made. The fear of being observed was also mentioned by other researchers as an important factor inhibiting EFL teachers' professional development (Çelik, Mačianskienè, \& Aytın, 2013; Lasagabaster \& Sierra, 2011). However, as one of the teachers in the LS group takes the role of a teacher while others observe students, LS can be used as a way of overcoming the fear of teaching in front of others and the follow-up critiques about the lesson (Eraslan, 2008).

In terms of the integration of LS into the EFL context in Turkey, there is a need to discuss the principles of ideal in-service EFL teacher training. Daloğlu (2004) categorizes in-service English teacher training programs as ongoing and one-shot. She suggests that rather than one-shot workshops organized as topdown in-service training opportunities, there should be school-embedded participatory teacher development programs that can make teachers' voices be heard, and thus increase their sense of ownership of professional development activities. Many other researchers underline the need for ongoing efforts in professional development instead of one-shot training activities (Altan, 2006; Mačianskienè \& Tuomaitè, 2004; Korkmazgil \& Seferoğlu, 2013). As a school-embedded, even as a lesson-embedded professional development method, LS is worth implementing as a means of professional development for EFL teacher training in Turkey.

For an effective integration of LS into the Turkish education system, Eraslan (2008) recommends that LS application can be initially embarked on a selected pilot university and its affiliated schools. Finally, depending on the success of the pilot project, it can be extended to all elementary and secondary schools in Turkey. He goes one step further by emphasizing the need to set up LS networks across the country and a common LS electronic database enabling the sharing of successful LS practices with colleagues teaching the same curriculum. As a good starting point, he believes that an external reward (e.g., paying for each LS application) should be given to teachers. He even argues that LS procedure can also be used in pre-service teacher training. He exemplifies his argument as follows: "Like in Japan, while one of these prospective teachers teaches his or her lesson, other prospective teachers, the cooperating teacher, and the universitybased mentors observe from the back of the classroom. At the end of the school day, they all come together and reflect and comment on the lesson in terms of the strengths and weaknesses." (p.65) The use of LS in pre-service teacher training programs was also supported by some other researchers (Vandeweghe \& Varney, 2006; Marble, 2006).

In conclusion, it was obvious that teachers participating in this study made significant gains as a result of the LS cycle. The teachers were generally of the opinion that the lesson was very helpful and did provide the students with a more interesting set of activities, which made the event enjoyable for all involved. They also felt that this was a solid professional development activity. However, as the current study is a case study whose results cannot be generalized, there is a need for more LS projects in other EFL contexts. To evaluate the effectiveness of LS in terms of EFL teachers' professional development, more research studies should be conducted with more students and teachers.

\section{REFERENCES}

Altan, M. Z. (2006). Preparation of foreign language teachers in Turkey: A challenge for the 21 st century. Dil Dergisi, 134, 49-54.

Burns, A. (1999). Collaborative action research for English language teachers. Cambridge: Cambridge University Press.

Cerbin, W., \& Kopp, B. (2011). Lesson study guide. Retrieved from http://www.uwlax.edu/sotl/lsp/guide

Çelik, S., Mačianskienè, N., \& Aytın, K. (2013). Turkish and Lithuanian EFL instructors' professional development experiences: Worth the effort, or waste of time? Erzincan University Faculty of Education Journal, 15(2), 160-187.

Daloğlu, A. (2004). A professional development program for primary school English language teachers in Turkey: Designing a materials bank. International Journal of Educational Development, 24, 677-690.

Darling-Hammond, L., \& McLaughlin, M. W. (1995). Policies That Support Professional Development in an Era of Reform. Phi Delta Kappan, 76(8), 597-604.

Dinçer, A., \& Yeşilyurt, S. (2013). Pre-service English teachers' beliefs on speaking skill based on motivational orientations. English Language Teaching, 6(7), 88-95. 
Dudley, P. (2011). Lesson Study: a Handbook. Online available from http://lessonstudy.co.uk/wpcontent/uploads/2012/03/Lesson_Study_Handbook_-_011011-1.pd

Eraslan, A. (2008). Japanese Lesson Study: Can it work in Turkey. Education and Science, 33, 62-67.

Fernandez, C. (2005). Lesson study: A means for elementary teachers to develop the knowledge of mathematics needed for reform minded teaching? Mathematical Thinking and Learning, 7(4), 265289.

Harding, K. (2009). CPD. Modern English Teacher, 18(3).

Hargreaves, D. H. (2012). A self improving school system: towards maturity. Nottingham, NCSL.

Hill, H. C., Rowan, B., \& Ball, D. (2005). Effects of Teachers' Mathematical Knowledge for Teaching on Student Achievement. American Educational Research Journal, 42(2), 371-406.

Johnson, K. E. (2009). Second Language Teacher Education: A Sociocultural Perspective New York: Routledge.

Karabenick, S., \& Noda, P. (2004). Professional development implications of teacher's beliefs and attitudes towards English language learners. Bilingual Research Journal, 28, 55-75.

Kıncal, R. Y., \& Beypınar, D. (2015). Ders Araştırması uygulamasının matematik öğretmenlerinin mesleki gelişimlerine ve öğrenme sürecinin geliştirilmesine etkisi. Mehmet Akif Ersoy Üniversitesi Eğitim Fakültesi Dergisi, 33, 186-210.

Kırkgöz, Y. (2007). Language planning and implementation in Turkish primary schools. Current Issues in Language Planning, 8(2), 174-192.

Korkmazgil, S., \& Seferoğlu, G. (2013). Exploring Non-native English Language Teachers' Professional Development Practices, Boğaziçi University Journal of Education, 30(1), 77-85.

Kourieos, S. (2012). The impact of mentoring on language teacher development during the practicum. ELTED, 15, 57-64.

Lasagabaster, D., \& Sierra, J. M. (2011). Classroom observation: Desirable conditions established by teachers. European Journal of Teacher Education, 34(4), 449-463.

Lave, J., \& Wenger, E. (1991). Situated Learning: Legitimate Peripheral Participation. Cambridge: Cambridge University Press.

Lee, J. F. K. (2008). A Hong Kong case of lesson study: Benefits and concerns. Teaching and Teacher Education, 24, 1115-1124.

Lewis, C. (2002). Lesson study: A handbook of teacher-led instructional improvement. Philadelphia: Research for Better Schools.

Lewis, C., Perry, R., \& Hurd, J. (2004). A deeper look at lesson study. Educational Leadership, 61, 5, 18-23.

Lewis, C., Perry, R., Hurd, J., \& O'Connell, M. P. (2006). Lesson study comes of age in North America. Phi Delta Kappan, 88(4), 273-281.

Mačianskienè, N., \& Tuomaitè, V. (2004). Learning strategies in foreign language teacher professional development. European added value in teacher education: the role of teachers as promoters of basic skills acquisition and facilitators of learning. Collection of the selected papers presented at the ATEE 7th Spring University, Tartu, 40-46.

Marble, S. T. (2006). Learning to teach through lesson study. Action in Teacher Education, 28(3), 86-96.

Murata, A., \& Takahashi, A. (2002). Vehicle to connect theory, research, and practice: how teacher thinking changes in district-level lesson study in Japan. Paper presented at the Twenty-fourth annual meeting of the North American chapter of the international group of the Psychology of Mathematics Education, Columbus, Ohio.

Nami, N. S., Marandi, S. S., \& Sotoudehnama, E. (2015). CALL teacher professional growth through lesson study practice: An investigation into EFL teachers' perceptions. Computer Assisted Language Learning.

Nunan, D. (1991). Communicative Tasks and the Language Curriculum. TESOL Quarterly, 25(2), 279-295.

Özmusul, M. (2011). Teachers' professional development: Analysis of Ireland, Lithuania and Turkey. EJournal of New World Sciences Academy, 6(1), 394-405.

Roback, P., Beth, C., Legler, J., \& Moore, T. (2006). Applying Japanese lesson study principles to an upper level undergraduate statistics course. Journal of Statistics Education, 14(2).

Rock, T. C., \& Wilson, C. (2005). Improving teaching through lesson study. Teacher Education Quarterly. 7793.

Schilling, J. (2006). On the pragmatics of qualitative assessment: Designing the process for content analysis. European Journal of Psychological Assessment, 22(1), 28-37.

Seferoğlu, S. S. (1996). Exploring elementary school teachers' perceptions of professional development: The Turkish case. Paper presented at the annual meeting of the American Educational Research Association, New York, NY. 
Stepanek, J., Appel, G., Leong, M., Mangan, M. T., \& Mitchell, M. (2007). Leading Lesson Study: A practical guide for teachers and facilitators. Thousand Oaks, CA: Corwin.

Stigler, J., \& Hiebert, J. (1999). The teaching gap. New York: The Free Press.

Şad, S. N. (2010). Theory-Practice Dichotomy: Prospective Teachers' Evaluations about Teaching English to Young Learners. The Journal of Language and Linguistic Studies, 6(2), 22-53.

Tanaka, H. (2007). Lesson Study as In-School Training. In Isoda, M., Stephens, M., Ohara, Y., Miyakawa, T. (Eds.) Japanese Lesson Study in Mathematics: Its Impact, Diversity and Potential for Educational Improvement (pp.150-153).Singapore: World Scientific Publishing.

Tasker, C. T. (2014). Exploring EFL teacher professional development through lesson study: An activity theoretical approach (Unpublished doctoral thesis). The Pennsylvania State University.

Tercanlığlu, L. (2004). Exploring gender effect on adult foreign language learning strategies. Issues in Educational Research, 14, 181-193.

Tsui, A. B. M., \& Law, D. Y. K. (2007) Learning as boundary crossing in school-university partnership. Teaching and Teacher Education, 23(8), 1289-1301.

Uysal, H. H., \& Bardakçı, M. (2014). Teacher beliefs and practices of grammar teaching: Focusing on meaning, form, or forms? South African Journal of Education, 34(1), 1-16.

Vandeweghe, R., \& Varney, K. (2006). The evolution of a schoolbased study group. Phi Delta Kappan, 88, 282-286.

Correspondence

Assist. Prof. Dr. Abdullah COŞKUN e-mail: coskun_a@ibu.edu.tr 